\section{Opinion and fact and UK energy}

SIR - John Surrey and Mike Parker have firmly held opinions on nuclear power (Nature 361, 677-680; 1993), but they should not be construed as facts.

Opinion: "New nuclear stations were uneconomic when the discount rate was raised to $8 \%$ in $1988 \ldots$ The breakthrough with nuclear capital costs has not been achieved.

Fact: Sizewell B is ahead of schedule, within the $£ 2.03$ billion budget which includes all first-of-a-kind costs, will be profitable and will contribute significantly to Nuclear Electric's future cash flow. A twin pressurized water reactor (PWR) Sizewell $C$, replicating the design, has been costed in detail. It could be built, operated for 40 years, fully decommissioned - and still produce at well under 3 pence per unit at an 8 per cent rate of return, competitive with new coal, new gas and French nuclear stations. The design is exciting international interest; Westinghouse has asked Nuclear Electric to join it in a joint bid for Taiwan's new nuclear station on precisely this design.

Opinion: ". . . it will not be known until Sizewell B has been operating for some years whether the PWR will become the established nuclear option that has been sought for 30 years."

Fact: With more than 150 operating worldwide over 30 years, the PWR already is the established international option. The Sizewell B design is based on the Westinghouse reactors operating for the past eight years at Wolf Creek and Callaway in the United States. Both stations routinely appear at the top of the performance league, with load factors well in excess of 80 per cent. Sizewell B, with enhanced diversity in control and monitoring systems, will certainly produce at over 85 per cent load factor.

Opinion: "The total liability for nuclear decommissioning costs now stands at $£ 18-£ 20$ billion . . . $£ 5.4$ billion for the Magnox stations and $£ 4.2$ billion for the AGRs ..."

Fact: The authors have chosen here to quote undiscounted and out-of-date figures although they make much play of discount rates elsewhere in their article and must be aware that the decommissioning costs concerned arise over a very long period of time stretching to the end of the twenty-first century and beyond. As our evidence to the Select Committee showed, we have made full provision for these costs in our accounts. Their present value is $£ 2.5$ billion using a very conservative discount rate of 2 per cent. The Select Committee suggested that these costs might actually be too high and it is true that if our 'Safestore' stategy is adopted we will be able to reduce the liability by at least a further $£ 500$ million. It is completely irrelevant to quote the decommissioning costs associated with Ministry of Defence activities in what purports to be an article about civil nuclear power.

Opinion: "Nuclear objectives proved inherently more difficult to achieve . .."

Fact: Yes - until 1989. Since then, Nuclear Electric is achieving them. In less than three years, output is up 25 per cent to record levels, productivity is up 50 per cent, unit costs are down by almost a third, and Sizewell B is ahead of schedule and within budget.

Opinion: "The levy... which finances more than half of nuclear generating costs."

Fact: No it doesn't. Nuclear Electric inherited liabilities from CEGB operations of $£ 10.5$ billion, without any of the provisions to cover them. The levy, which reduces in real terms year on year, will raise a total of $£ 9.1$ billion. However you do the sums, the levy is clearly there to pay for history; the Select Committee said it is "indefensible that so much of the burden of discharging the pre-April 1990 liabilities should be placed on electricity consumers within one eight-year period". But to suggest it's an inevitable part of our continuing generation costs is simply wrong. It has nothing to do with the commercial future of nuclear power.

Still, there's one overriding opinion on which we can all agree. As Surrey and Parker put it: "Whatever decisions flow from the government's policy review, it is important to understand the background... Throughout, there was no formal framework of energy policy."

Let's get it right this time.

John G. Collier

(Chairman)

Nuclear Electric plc,

Barnett Way, Barnwood,

Gloucester GL4 7RS, UK

\section{Patent problems}

SIR - Your leading article (Nature 361, $192 ; 1993)$ on the patenting of transgenic plants illustrates some of the complexities being faced by the European Patent Office from applications to patent transgenic agricultural plants and animals. You highlight the problems likely to become apparent should animal breeds or plant varieties be patented; there would be established a double system of monopoly rights and subsequent confusion over ownership. No doubt lawyers would be happy with this but conventional breeding programmes could well suffer.

Article 53 (b) of the European Patent
Convention (EPC) currently excludes plant varieties from patentability. The response of appellant patentee lawyers has been to claim exclusive rights to 'plants' which will, in fact, include all varieties of plants containing the gene in question. Besides being a linguistic contortion to avoid the use of the phrase 'plant variety', this all-embracing course of action seems merely to exacerbate the problems.

Of equal significance to biologists is another part of Article 53 (b) which prohibits the patenting of 'essentially biological processes'. This was included, no doubt, because those who drafted the convention wished to avoid the patenting of living matter, although an exception was made for microbiological processes. Applicants for patents on transgenic organisms are now arguing that where the inserted genes come from microbiological sources, the organisms being patented have suddenly become microbiological. Second, they argue that because human intervention is involved in the production of transgenic plants or animals, they have somehow ceased to be biological and thus patentable. Such assertions run contrary to the organizational and integrative principles of biology. It is crucial that more biologists now join this debate on the patenting of life forms to forestall the conveyance of their subject into a legalistic and linguistic Wonderland.

A patent is also meant to be granted in the public interest and the exclusion clause concerning public order and morality is to ensure that patents fulfil this obligation. The granting of patents on plants rewards a technology that could lead to the genetic pollution of nature, an outcome that is clearly not in the public interest. The wording of the EPC, however, is difficult to apply to morality issues surrounding genetically engineered organisms for exactly the same reasons that difficulties arise over 'essentially biological processes' - the drafters of the convention did not envisage patenting of plants and animals.

The European Patent Office has got itself into a mess over these issues because it has proceeded to patent life forms without first examining properly whether the EPC, when interpreted as it was originally intended, actually allows the patents the patent office has granted. It has allowed itself to be pushed into juggling words to fit industries' interests and has ignored the legitimate moral concerns of many. What it should do is to stop issuing patents for plants and animals and await the outcome of proper international debate.

\section{Susan Mayer}

(Director of Science)

Greenpeace,

Canonbury Villas, London N1 2PN, UK 